\title{
Determinants of mergers and acquisitions among Finnish cooperative and savings banks
}

\author{
Matias Huhtilainen $^{1}$ D . Jani Saastamoinen ${ }^{1} \cdot$ Niko Suhonen $^{1}$
}

Accepted: 19 June 2021 / Published online: 30 June 2021

(c) The Author(s) 2021

\begin{abstract}
This study is the first to examine mergers and acquisitions among small, regional stakeholder banks that belong to the same group. Using data on Finnish unlisted cooperative and savings banks, we investigate the relationship between bank-specific factors and the likelihood of a bank being an acquirer or an acquisition target. We find that large banks tend to acquire small and inefficient banks. Additionally, we examine the loan growth and find a negative (positive), statistically significant association with the likelihood of a bank being an acquisition target (acquirer). Finally, we document an increase in the likelihood of a bank being an acquisition target subsequent to an increase in the share of net fees and commission income against total assets.
\end{abstract}

Keywords Mergers and acquisitions $\cdot$ Stakeholder banks $\cdot$ Banking sector consolidation

JEL Classification C35 - G21 - G34 · L22

\section{Introduction}

Cooperative and savings banks are an important part of the banking system. These regional, often small stakeholder banks tend to focus on local markets and niche market segments, which provides them with a competitive advantage over larger rivals $[5,7,19,44]$. They are a major source of funding for small businesses and hold a significant market share in relationship lending both in the USA [20, 47] and in Europe [35, 43, 44, 49].

However, the ongoing technological progress, product and service innovations, changes in customer preferences and intensifying competition have urged smaller banks to pursue growth [7, 20, 27]. One option to pursue growth is to merge with rivals. Consequently, mergers and acquisitions (M\&A) in the banking sector have been a driver of banking sector consolidation $[38,53]$, resulting in a decline in the

Matias Huhtilainen

matias.huhtilainen@uef.fi

Jani Saastamoinen

jani.saastamoinen@uef.fi

Niko Suhonen

niko.suhonen@uef.fi

1 Business School, University of Eastern Finland, Yliopistokatu 2, 80100 Joensuu, Finland number of individual banks in Western economies [13, 25, 40, 45, 48, 51, 52].

In general, a merger requires the acquirer-target pair to find a joint match value, which maximizes both parties' individual payoffs $[2,18]$. Prior research suggests a rough dichotomy between internal and external motives for bank mergers and acquisitions (M\&A). ${ }^{1}$ Namely, acquirers search for economies of scale and other efficiency gains. They also want to increase their market share, broaden their customer base, boost revenue growth, diversify business and product lines and/or alter their risk profile through asset restructuring $[2,11,22,23,48]$. In terms of lending expansion, Cyree [15] suggests that acquirers prefer targets with sufficient core deposits, as they provide a stable, high-quality funding source. Furthermore, the M\&A activity in the banking sector is also driven by external factors such as regulatory and institutional environment, macroeconomic development, and competition. [11, 12, 18, 37]

While the larger and often listed commercial banks have received much attention in the banking sector M\&A

\footnotetext{
${ }^{1}$ In comparison, Berger et al. [6] propose a separation between shareholder wealth-maximizing and non-value-maximizing motives. The latter influence the decision-making if non-owner stakeholderstypically the management, but occasionally even the government of the bank's home country-promote the merger. Namely, managers may be tempted to engage in empire building since executive compensation tends to increase with firm size.
} 
literature (e.g., [1, 17, 29, 30], among others), research into the determinants of M\&A among regional, often small, stakeholder banks is scarcer (e.g., [8, 26, 54]). In a study of industry consolidation in the US market, Goddard et al. [25] find that small, old, and highly capitalized credit unions are at a higher risk of acquisition. Likewise, a high proportion of liquid assets, low profitability, and a low loans-to-assets ratio predict a higher risk of failure or acquisition. Worthington [54] investigated Australian credit unions and found that managerial ability, size and profitability best predict which banks end up being acquirers, whereas small size, a shared associational bond, and a lower level of liquidity correlate with the likelihood of being a target bank. A study of mergers between Portuguese agricultural credit cooperatives by Cabo and Rebelo [8] suggest that acquirers tend to be large, profitable, and have good credit management, whereas target banks are small, lack economies of scale and exhibit overleverage and weak credit management.

Small stakeholder banks often assume a group structure in which individual banks operate under a common central institution that provides them with services relating to liquidity, risk management, marketing, and investment banking [28]. However, research into the M\&A activity within bank groups consisting of independent member banks is non-existent. Yet, similar forces that drive consolidation in the banking market overall may also manifest themselves within the groups of stakeholder banks. To fill this gap in the literature, we ask: which factors predict mergers among small stakeholder banks that are part of the same group? In accordance, we employ a panel data set of Finnish unlisted cooperative and savings banks over the period of 2002-2018 and examine the relationship between bank-specific factors and the likelihood of a bank being an acquirer or, conversely, an acquisition target. Moreover, we specifically focus on Finland where these type of small, regional stakeholder banks hold a significant market share in deposits, mortgages, and SME lending [43, 49].

This paper contributes to the literature in three primary ways. To our best knowledge, this study is the first to examine the determinants of intra-group M\&A in the banking sector. Second, unlike numerous previous studies, we observe stakeholder banks that are small, unlisted, and regionally oriented. Finally, we add to the banking sector M\&A literature by examining a small but developed European market where banks in general and the regional stakeholder banks in particular play an unusually pivotal role in the economy. Even though the geographical focus is limited as such, it allows us to control for cross-country variation, hence increasing our ability to make more reliable inferences from the data.

The rest of the paper is organized as follows. In the next section, we discuss prior findings and develop testable hypotheses for our variables of interest. Section 3 describes the data and methodology, and Sect. 4 reports the results.
Finally, we conclude the paper, discuss certain country- and bank type-related implications and suggest venues for future research.

\section{Hypothesis development}

\section{Capitalization}

Using a sample of 777 deals involving EU-based acquirers, Beccalli and Frantz [4] find that both acquirers and targets carry relatively low capital-to-assets ratios. They suggest that, on the one hand, highly leveraged targets are likely to be less expensive to acquire, and hence, more attractive to potential buyers. On the other hand, high leverage among acquirers may indicate competent management capable of operating successfully despite the leverage.

Pasiouras et al. [48] investigated EU bank takeovers from 1997 to 2002 and concluded that both targets and acquirers were less capitalized compared to non-involved banks. Lanine and Vander Vennet [41] studied cross-border acquisitions involving Western-European acquirers and EasternEuropean targets and found that both targets and acquirers were less capitalized than their domestic competitors. Likewise, Carbo-Valverde et al. [11] examined 47 domestic deals in Spain and concluded a negative and positive association between solvency and the probability of being a target bank and an acquirer, respectively. On the other hand, Goddard et al. [25] suggested that highly capitalized credit unions were at a higher risk of acquisition.

Based on the inconsistent results concerning the directionality of capitalization, we propose the following nondirectional hypotheses:

H1a Capitalization is associated with the likelihood of being an acquirer.

H1b Capitalization is associated with the likelihood of being a target.

\section{Size}

The evidence regarding bank size is somewhat mixed. Hannan and Piloff [30] conclude that large banks tend to acquire large banks, which they suggest indicates the presence of economies of scale in the acquisition process, whereby it is more desirable to acquire one large bank than several smaller ones. Employing an international sample of 179 countries and 220 cross-border acquisitions over the period 1994-2003, Correa [14] found size to increase the likelihood of being a target bank in a cross-border deal. Likewise, Caiazza et al. [9] and Akhigbe et al. [1] captured a positive 
and highly significant association between size and the probability of a bank being an acquisition target.

Pasiouras et al. [48] concluded that both targets and acquirers were larger compared to their non-involved competitors. Similarly, Lanine and Vander Vennet [41] found that both targets and acquirers were larger than their domestic peers. Contradictory findings have been reported by Wheelock and Wilson [53], Goddard et al. [26] and CarbóValverde et al. [11] who all found a negative association between size and the probability of being acquired. Similar findings are also reported in Worthington [54], Cabo and Rebello [8] and Goddard et al. [25].

For acquirers, the prior findings are somewhat consistent. Hence, we propose the following directional hypothesis:

H2a Bank size is positively associated with the likelihood of being an acquirer.

However, in terms of target banks, the results are more inconclusive. Thus, we propose the following non-directional hypothesis:

$\mathrm{H}$ 2b Bank size is associated with the likelihood of being a target.

\section{Performance}

Caiazza et al. [9] suggest that efficient banks tend to acquire banks that are less efficient. Pasiouras et al. [48] found acquirers to be more efficient than targets, although both targets and acquirers were more inefficient compared to noninvolved banks. Secondly, they concluded that targets were less profitable with lower growth prospects and acquirers were more profitable with higher growth prospects. Similarly, Goddard et al. [25], Goddard et al. [26], Hannan and Pilloff [30], Campa and Hernando [10] and Akhigbe et al. [1] documented lower premerger profitability for target banks.

Worthington [54] found that managerial ability and profitability increased the likelihood of being an acquirer, whereas a shared associational bond and a lower level of liquidity were found more often among target banks. Cabo and Rebelo [8] suggest that acquirers tend to be profitable and demonstrate good credit management as opposed to target banks, which exhibit weak credit management and high leverage. Frame and Coelli [24] found the less efficient corporate credit unions disappeared from the market at a relatively higher rate.

Beccalli and Frantz [4] found target banks to be relatively more illiquid as well as more inefficient, whereas acquirers were more efficient. Carbó-Valverde et al. [11] documented higher levels of inefficiency to be significantly and positively associated with the probability of being a target bank.
Meanwhile, Correa [14] identified a likely target in a crossborder deal to be a bad performer in a small country with a concentrated banking sector. Hernando et al. [32] suggest inefficient banks are more likely to be targets in domestic deals, whereas in the context of cross-border mergers, the impact is mixed.

On one hand, the use of efficiency measure suggests that inefficient and less profitable banks are no more likely to become acquisition targets. However, when measured relative to the median of the market in which the target bank operates, inefficiency increases the likelihood of being acquired and the effect is statistically significant. Meanwhile, Lanine and Vander Vennet [41] found acquired banks not to be less efficient compared to their domestic competitors. Wheelock and Wilson [53] found that inefficiency actually decreases the probability of being acquired.

Since the prior literature mostly suggests that acquirers, as opposed to targets, exhibit a higher level of (relative) efficiency, we propose two directional hypotheses:

H3a Efficiency is positively associated with the likelihood of being an acquirer.

H3b Efficiency is negatively associated with the likelihood of being a target.

In terms of profitability, we expect the following:

H4a Profitability is positively associated with the likelihood of being an acquirer.

H4b Profitability is negatively associated with the likelihood of being a target.

\section{Business model}

Banks' revenue streams consist of interest (traditional financial intermediation) and non-interest income (fees and commissions, trading, and other operating income). Some studies suggest that higher income diversification favors bank profitability, while others conclude that an increase in the share of non-interest income is associated with a corresponding increase in a bank's riskiness vis-à-vis to institutions that mainly carry out traditional intermediation activities [3, 42].

On the other hand, Huhtilainen [33] reports a negative relationship between the degree of specialization in traditional banking and the risk of insolvency. Köhler [39] examined the impact of non-interest income on risk in the German banking sector and concluded that the noninterest income of savings and cooperative banks is, on average, less volatile. However, Köhler [39] also notes that among savings and cooperative banks, the non-interest income is more correlated with net interest income, thus 
reducing their chances of income diversification. That is, (savings and cooperative) banks face a trade-off between income volatility and correlation between different income sources.

In this study, we look at whether mergers and acquisitions are driven by banks' business orientation or, in other words, the "traditionalism" of their business model. For instance, Focarelli et al. [23] found that acquirers generated a higher share of income from services whereas target banks were more oriented toward financial intermediation. Beccalli and Frantz [4] characterized acquirers as "reasonably diversified banks" that, unlike target banks, are less specialized in traditional banking. We examine this association by calculating the banks' net fee and commission income as a percentage of their total assets. Based on Focarelli et al. [23] and Beccalli and Frantz [4], we test the following hypotheses:

H5a The net fee and commission income as a percentage of total assets is positively associated with the likelihood of being an acquirer.

H5b The net fee and commission income as a percentage of total assets is negatively associated with the likelihood of being a target.

Some evidence indicates a negative association between the loans-to-assets ratio and the probability of being a target bank [25, 26, 48]. Goddard et al. [26] suggest that this finding could be a result of potential acquirers anticipating a higher return on assets through a deal. On the other hand, Hannan and Rhoades [31] hypothesize that a high level of loan activity indicates strong market penetration, hence making the bank a more attractive acquisition target. For acquirers, Pasiouras et al. [48] captured a positive effect although it was not significant in every estimation. Looking at deals in which a bank merely purchases a controlling stake in another bank, Focarelli et al. [23] found that both banks tended to have a high share of loans on total assets. After considering these findings, we propose that:

H6a The loans-to-assets ratio is associated with the likelihood of being an acquirer.

H6b The loans-to-assets ratio is negatively associated with the likelihood of being a target.

Finally, Moore [46] and Pasiouras et al. [48] found a negative association between asset growth and the likelihood of becoming a target, whereas Hernando et al. [32] concluded that the annual total asset growth rate did not display any significant predictive power in terms of which bank would be acquired. In the context of acquirers, Pasiouras et al. [48] and Beccalli and Frantz [4] found that banks with a greater historical growth were more likely to become acquirers. Hence, our last hypotheses are as follows:

H7a Loan growth is positively associated with the likelihood of being an acquirer.

H7b Loan growth is associated with the likelihood of being a target.

\section{Research design}

\section{An overview of the Finnish banking sector}

At the end of 2018, there were 255 credit institutions, both deposit banks and other non-deposit-taking credit institutions, such as finance houses, credit card companies and mortgage credit banks, operating in Finland [21]. Table 1 lists the credit institutions, which are under the supervision of the Financial Supervisory Authority of Finland (FINFSA). The Finnish banking sector is somewhat concentrated: the market share of the four largest banks is $80 \%$, with the largest one having a $40 \%$ share in deposits, housing loans and corporate loans. From the European perspective, another distinctive feature of the Finnish banking sector is the cooperative banks' comparatively high share of the credit market [43].

Cooperative banking in Finland originated and subsequently joined the already established networks of commercial and savings banks in the early twentieth century. Initially, cooperative banks operated in limited geographical areas with the primary purpose of intermediating agricultural loans made by the Finnish government to small farmers, who typically lacked access to credit from commercial and savings banks [36]. As of today, the two largest commercial banks have effectively closed their branches outside the most populated urban areas, whereas savings banks and in particular cooperative banks continue to maintain relatively extensive branch networks across Finland. In consequence, retail banking in Finland has largely become a regional business where stakeholder banks have established several monopoly-like positions in the rural parts of the country [34].

The sample banks of this study consist of independent member banks that belong to the amalgamations of cooperative or savings banks, as described in Table 1. Throughout the paper, we use the term "bank group" to refer to these amalgamations. They form a network of independent cooperative or savings banks, which operate under a common central institution, which provides the member banks with services, including liquidity and risk management, payment settlements, money transfers within the banking system, advertising, and investment banking [28]. Second, whenever 
Table 1 A list of credit institutions under the supervision of FIN-FSA at the end of 2018

\begin{tabular}{|c|c|c|c|}
\hline Institution & Structure & $\begin{array}{l}\text { Assets (million } \\
\text { EUR) }\end{array}$ & $\begin{array}{l}\text { Included in } \\
\text { the sample }\end{array}$ \\
\hline Nordea $^{\mathrm{a}}$ & Commercial bank & 551,400 & No \\
\hline OP Financial Group ${ }^{a}$ & Amalgamation of 156 cooperative banks and other subsidiaries & 140,400 & Yes \\
\hline Municipality Finance ${ }^{a, b}$ & Special financial institution & 35,700 & No \\
\hline Savings Banks Group & Amalgamation of 23 member savings banks and other subsidiaries & 11,700 & Yes \\
\hline Aktia Bank & Commercial bank & 9300 & No \\
\hline S-Bank & Commercial bank & 6400 & No \\
\hline Danske Mortgage Bank & $\begin{array}{l}\text { Mortgage lender owned by Danske Bank A/S and part of Danske Bank } \\
\text { A/S, Finland Branch }\end{array}$ & 5900 & No \\
\hline Ålandsbanken & Commercial bank & 5600 & No \\
\hline POP Bank Group & Amalgamation of 26 cooperative banks and other subsidiaries & 4400 & Yes \\
\hline Hypo Group & $\begin{array}{l}\text { The Mortgage Society of Finland (mortgage lender) and Suomen Asunto- } \\
\text { HypoPankki (deposit bank) }\end{array}$ & 3100 & No \\
\hline Oma Savings Bank ${ }^{\mathrm{c}}$ & Commercial bank & 2900 & Yes \\
\hline Evli Bank & Commercial bank & 800 & No \\
\hline Handelsbanken Finance & Subsidiary of Svenska Handelsbanken AB & 500 & No \\
\hline
\end{tabular}

${ }^{a}$ Nordea, OP Financial Group and Municipality Finance are under the direct supervision of the European Central Bank (ECB)

${ }^{\mathrm{b}}$ Municipality Finance, established in 1989, is a special financial institution jointly owned by Finnish local governments, with the purpose of extending credit to its owners and commercial entities which are majority-owned by local governments [50]

' Oma Savings Bank belonged to the Savings Bank Group until 2014, after which it seceded from the group in order to continue its operations as an independent commercial bank

two or more banks representing the same group merge, we refer to this as an "intra-group M\&A."

\section{Data}

In this study, we examine unlisted Finnish savings and cooperative banks between 2002 and 2018. The data include annual financial figures collected and combined from the database of the financial supervisory authority of Finland. We identified and documented each merger and other events of relevance by utilizing and combining publicly available information from FIN-FSA, the banks themselves and from the electronic archives of local news outlets.

Over the study period, we observed a drop from 317 to 206 banks. Each bank belongs to one of the three (3) bank groups present in the data, and all but two (2) mergers occurred between banks that were part of the same group. Effectively, at some point in time, a bank is either:

1. Acquired by another bank; or

2. It joins one or more banks in order to establish a new credit institution with each party ceasing their independent existence (a merger of equals).

We did not examine the 55 banks that joined a merger of equals as a separate cluster but instead, combined them with target banks under a common category. From a methodical perspective, we emphasize the fact that there are as many as nine (9) years without any mergers of equals. ${ }^{2}$ From a logical perspective, we consider the two bank types to be sufficiently similar in the sense that both disappear from the data after the merger occurs.

Table 2 illustrates the within-sample fluctuations in the data. The column "Banks" indicates the number of all banks by year in the sample, whereas non-involved banks are those that do not take part in any merger or acquisition during the calendar year. The column "Acquirers" denotes banks engaging in a takeover of another bank or banks, whereas the last column "Targets" includes banks that are given a value of one in the year they are last observed as independent entities. However, in some cases, the actual closure of business may not take place until the following year.

\section{Explanatory variables}

In our selection of bank-specific predictors, we closely followed the example of prior studies (e.g., [4, 11, 23, 48], among others) to the extent of the data available. In particular, we relied on Hernando et al. [32], who investigated both domestic and cross-border bank mergers in EU-25 countries.

\footnotetext{
${ }^{2}$ Robustness checks suggest that our results are consistent and qualitatively similar regardless of excluding the 55 banks altogether or alternatively including them in the same category with acquirers (see Web Appendix).
} 
In a similar fashion, we considered the equity ratio, total assets, cost/income ratio and return on assets as proxies for banks' capitalization, size, efficiency, and profitability.

However, we also included the share of outstanding loans to total assets since Hannan and Rhoades [31] suggest that high and low levels of loan activity indicate aggressive and conservative management, respectively. Additionally, we substituted asset growth in Hernando et al. [32] with annual loan growth (excluding loans to other institutions) and instead of the market-level Herfindahl-Hirschman index by Hernando et al. [32], we assess the "traditionalism" of the banks' business model by calculating the net fee and commission income as a percentage of total assets.

For practical reasons, we refer to the net fee and commission income hereinafter as "non-interest income" even
[39] notes that German banks - and in particular, the savings and cooperative banks-generate most of their noninterest income from fees and commissions, whereas trading income is more important for the investment-oriented banks.

\section{Methods}

We model the probability that our response variable $\rho_{i t}$ equals one (1) if bank $i$ participates in a merger during year $t$ and zero (0) otherwise. The probabilities are estimated separately for acquirers and target banks. Hence, we define our baseline model as follows:

$$
\begin{aligned}
\rho_{i, t}= & \text { Constant } \beta_{1} \text { lnAssets }_{i, t-1}+\beta_{2} \text { CIR }_{i, t-1}+\beta_{3} \text { CAR }_{i, t-1}+\beta_{4} F C I_{i, t-1}+\beta_{5} \text { Loans }_{i, t-1} \\
& +\beta_{6} \text { Growth }_{i, t}+\beta_{7} \text { ROA }_{i, t-1}+\sum \gamma_{t} \text { Year }_{t}+\beta_{8} \text { Savings }_{i, t}+\varepsilon_{i, t} .
\end{aligned}
$$

though our data lack information on the banks' other noninterest income generating businesses, namely the net trading income and net other operating income [16]. However, this may not pose a significant shortcoming, as Köhler

Table 2 The annual numbers by category and year

\begin{tabular}{llllc}
\hline Year & Banks & $\begin{array}{l}\text { Non-involved } \\
\text { banks }\end{array}$ & Acquirers & Targets \\
\hline 2002 & 317 & 316 & & 1 \\
2003 & 319 & 319 & & \\
2004 & 319 & 318 & 1 & 1 \\
2005 & 318 & 311 & 2 & 6 \\
2006 & 313 & 305 & 4 & 6 \\
2007 & 308 & 303 & 1 & 1 \\
2008 & 307 & 292 & 2 & 14 \\
2009 & 297 & 282 & 3 & 13 \\
2010 & 288 & 269 & 3 & 16 \\
2011 & 276 & 259 & 5 & 14 \\
2012 & 264 & 248 & 10 & 11 \\
2013 & 253 & 230 & 4 & 12 \\
2014 & 241 & 225 & 9 & 4 \\
2015 & 230 & 217 & 4 & 12 \\
2016 & 227 & 213 & 6 & \\
2017 & 217 & 199 & 3 & 12 \\
2018 & 206 & 203 & & \\
\hline
\end{tabular}

Thirteen banks were involved in two deals: first as an acquirer and then either as an acquiree, again as an acquirer or as a party to a merger of equals. In addition, five entirely new banks emerged in the data during the observation period. Two banks were acquired by an out-of-sample commercial bank. Five banks seceded from their group and joined another group and finally, one bank seceded from its group to proceed as an independent institution where $\sum \gamma_{t}$ Year $_{t}$ denotes the set of year dummy variables and InAssets, CIR, CAR, FCI, Loans, Growth, ROA denote the natural logarithm of total assets, cost/income ratio, equity/ assets, non-interest income/assets, loans/assets, loan growth and return on assets, respectively. Finally, we control for possible bank type heterogeneity by including a dummy variable Savings $s_{i, t}$, which takes a value of one (1) for savings banks and zero (0) otherwise.

\section{Findings \\ Descriptive statistics}

In Table 3, we identify banks in three categories, "Acquirers," "Targets" and "Others." The last category consists of independent banks that were not involved in any type of merger or consolidation between 2002 and 2018.

First, we conclude that acquirers are, on average, larger than target and independent banks. While generating the highest non-interest income return on assets, acquirers also display the highest loan growth as well. Moreover, the acquirers carry the highest share of outstanding loans to total assets, which indicates managerial aggressiveness per the definition by Hannan and Rhoades [31]. Consistent with Pasiouras et al. [48], both targets and acquirers are, on average, less capitalized than the non-involved banks. Although the three groups are not distinctively different in terms of their profitability, we document the highest profitability for target banks. On the other hand, target banks also exhibit the greatest inefficiency, as measured by the cost/income ratio. 
Table 3 The descriptive statistics are calculated across all banks in their respective groups in all years without consideration of the panel data structure

\begin{tabular}{|c|c|c|c|c|c|c|c|c|}
\hline Variable & Mean & SD & p25 & p50 & p75 & Min & $\operatorname{Max}$ & Exp. sign \\
\hline \multicolumn{9}{|l|}{ Acquirers $(n=738)$} \\
\hline Assets & 410,953 & 594,120 & 87,640 & 178,492 & 437,895 & 16,313 & $3,826,789$ & + \\
\hline Cost/income ratio (CIR) & 60.82 & 13.11 & 51.6 & 60.45 & 70.1 & 14.8 & 137.78 & - \\
\hline Equity/assets (CAR) & 11.59 & 4.71 & 8.1 & 11.0 & 15.16 & 1.41 & 28.84 & $\mp$ \\
\hline Non-interest income/assets (FCI) & 54.47 & 18.57 & 40.74 & 53.79 & 67.12 & 10.04 & 116.31 & + \\
\hline Loans/assets (Loans) & 87.17 & 6.86 & 83.91 & 88.94 & 92.62 & 63.46 & 96.58 & $\mp$ \\
\hline Loan growth (Growth) & 8.66 & 13.4 & 2.93 & 6.63 & 10.41 & -26.53 & 128.84 & + \\
\hline Return on assets (ROA) & 1.07 & 0.59 & 0.66 & 0.96 & 1.42 & -0.34 & 6.57 & + \\
\hline Savings bank & 0.102 & 0.304 & 0 & 0 & 0 & 0 & 1 & \\
\hline \multicolumn{9}{|l|}{ Targets $(n=1346)$} \\
\hline Assets & 99,152 & 121,495 & 32,098 & 61,851 & 104,827 & 4,008 & 806,066 & $\mp$ \\
\hline Cost/income ratio (CIR) & 64.92 & 14.08 & 55.9 & 63.68 & 72.4 & 22.39 & 169.86 & + \\
\hline Equity/assets (CAR) & 11.89 & 3.85 & 9.15 & 11.73 & 14.24 & 2.84 & 27.75 & $\mp$ \\
\hline Non-interest income/assets (FCI) & 48.2 & 19.08 & 34.43 & 47.84 & 59.83 & -1.12 & 137.72 & - \\
\hline Loans/assets (Loans) & 86.17 & 8.53 & 82.01 & 88.66 & 92.53 & 46.02 & 98.13 & - \\
\hline Loan growth (Growth) & 7.01 & 5.96 & 3.2 & 7.4 & 10.7 & -20.08 & 33.56 & $\bar{\mp}$ \\
\hline Return on assets (ROA) & 1.14 & 0.60 & 0.70 & 1.16 & 1.54 & -0.949 & 4.08 & - \\
\hline Savings bank & 0.124 & 0.33 & 0 & 0 & 0 & 0 & 1 & \\
\hline \multicolumn{9}{|l|}{ Others $(n=2662)$} \\
\hline Assets & 188,108 & 437,344 & 48,539 & 80,185 & 152,693 & 10,218 & $10,095,361$ & \\
\hline Cost/income ratio (CIR) & 62.85 & 17.14 & 53.01 & 62.2 & 71.8 & 10.40 & 518.8 & \\
\hline Equity/assets (CAR) & 12.31 & 4.36 & 9.02 & 12.15 & 15.15 & 0.33 & 29.74 & \\
\hline Non-interest income/assets (FCI) & 47.33 & 20.43 & 32.96 & 45.72 & 60.45 & -8.11 & 130.41 & \\
\hline Loans/assets (Loans) & 85.42 & 7.78 & 80.58 & 86.78 & 91.69 & 47.51 & 98.99 & \\
\hline Loan growth (Growth) & 6.09 & 5.92 & 2.35 & 6.06 & 9.79 & -12.53 & 86.31 & \\
\hline Return on assets (ROA) & 1.04 & 0.669 & 0.58 & 0.93 & 1.42 & -5.18 & 6.43 & \\
\hline Savings bank & 0.125 & 0.331 & 0 & 0 & 0 & 0 & 1 & \\
\hline
\end{tabular}

For acquirers and targets, we include the expected signs of coefficients according to the research hypotheses outlined in Sect. 3.

Table 4 Results of the logit estimations

\begin{tabular}{|c|c|c|c|c|c|c|}
\hline \multirow[t]{2}{*}{ Variable } & \multicolumn{3}{|l|}{ Acquirers } & \multicolumn{3}{|l|}{ Targets } \\
\hline & Coefficient & SE & $p$ value & Coefficient & SE & $p$ value \\
\hline ln assets, $\mathrm{t}-1$ & 0.705 & 0.151 & 0.000 & -0.349 & 0.110 & 0.001 \\
\hline Cost/income ratio, $\mathrm{t}-1$ & -0.005 & 0.013 & 0.700 & 0.023 & 0.007 & 0.001 \\
\hline Equity/assets, t - 1 & 0.066 & 0.050 & 0.186 & 0.042 & 0.029 & 0.144 \\
\hline Non-interest income/assets, $\mathrm{t}-1$ & 0.001 & 0.011 & 0.961 & 0.012 & 0.005 & 0.018 \\
\hline Loans/assets, t - 1 & 0.015 & 0.023 & 0.518 & -0.007 & 0.013 & 0.580 \\
\hline Loan growth & 0.102 & 0.035 & 0.003 & -0.069 & 0.018 & 0.000 \\
\hline Return on assets, $\mathrm{t}-1$ & 0.091 & 0.282 & 0.747 & 0.121 & 0.279 & 0.664 \\
\hline Savings bank & -0.082 & 0.560 & 0.884 & 0.200 & 0.332 & 0.547 \\
\hline Constant & -15.887 & 3.435 & 0.000 & -0.783 & 1.884 & 0.678 \\
\hline Year effects & Yes & & & Yes & & \\
\hline Obs. & 3723 & & & 3837 & & \\
\hline Wald $(20) \chi^{2}$ & $112.53 * * *$ & & & $86.49 * * *$ & & \\
\hline
\end{tabular}

***Significant at the $0.1 \%$ level. Robust standard errors 


\section{Results}

Table 4 reports the results for the empirical model. The coefficients in Table 4 represent differences in log odds subsequent to a one-unit increase in the predictor's value.

First, we find that the estimated coefficient on (natural logarithm) of assets is positive (negative) and significant for acquirers (targets). Thus, we conclude that larger banks tend to acquire smaller banks and in consequence, we do not reject the hypotheses $\mathrm{H} 2 \mathrm{a}$ and $\mathrm{H} 2 \mathrm{~b}$. However, we reject $\mathrm{H} 3 \mathrm{~b}$ and suggest that the more inefficient the bank, the more likely it will be acquired. On the other hand, there is no indication that operational efficiency would influence the likelihood of being an acquirer.

Third, we capture a positive association between the noninterest income and the likelihood of being a target. Thus, we reject H5b. On the contrary, we find evidence to support hypotheses $\mathrm{H} 7 \mathrm{a}$ and $\mathrm{H} 7 \mathrm{~b}$, as the coefficient on loan growth is positive (negative) for acquirers (targets).

The rest of the coefficient estimates are statistically insignificant. For this reason, we reject research hypotheses H1a, H1b, H3a, H4a, H4b, H5a, H6a and H6b.

\section{Robustness checks}

We carried out additional analyses to check that our results were robust to alternative model specifications. The results of these estimations are reported in a separate Web Appendix. First, we checked if the results are sensitive to the observation period by inspecting the time periods from 2002 to 2008 and from 2009 to 2018 separately. Second, we estimated the empirical model by including the banks involved in mergers of equals into the same group as the acquirers. Finally, we estimated the empirical model after excluding the banks involved in mergers of equals from the data altogether. The additional analyses yielded results that were qualitatively similar to the ones presented in the paper. This suggests that our findings are robust to these alternative model specifications.

\section{Conclusions}

\section{Discussion}

Focusing on intra-group M\&A between small Finnish stakeholder banks, we uncovered several firm-specific factors demonstrating some predictive power in terms of which type of banks are a more likely to be acquisition targets and conversely, acquirers. At first, we failed to identify the presence of economies of scale as per the definition in Hannan and Piloff [30]. Rather, our results indicate that large banks tend to acquire small banks. The negative association between size and the probability of being an acquisition target is consistent with Wheelock and Wilson [53], Goddard et al. [26] and Carbó-Valverde et al. [11].

In the context of this study, this finding may reflect the rather steep urbanization trend in Finland since the observed acquisition targets were predominately located in geographical areas with declining demographics. Substantiating our interpretation that the banking sector is concentrating on areas with a more robust economic and demographic outlook, we found that loan growth displayed a negative (positive), statistically significant association with the likelihood of bank being an acquisition target (acquirer).

Contradictory to Wheelock and Wilson [53], but consistent with Hernando et al. [32] and Carbó-Valverde et al. [11], we found that inefficient banks are a more likely acquisition target. Considering these findings so far, we strongly suspect our results are at least partly affected by group-level managerial advocacy for the smaller, inefficient units with modest growth prospects to be absorbed into larger entities that operate in a more favorable business environment.

As for banks' business model, we have documented an increase in the likelihood of a bank being an acquisition target subsequent to an increase in non-interest income as a percentage of the bank's total assets. Substantially, this finding contradicts Focarelli et al. [23] and Beccalli and Frantz [4] who concluded that target banks are more oriented toward traditional financial intermediation. However, we avoid any decisive conclusions in this regard despite our earlier suggestion that some of the mergers and acquisitions may be motivated by the strategic objective of broadening their customer base and diversifying revenue streams. It is noteworthy that neither the cost/income ratio nor the noninterest income as a percentage of the bank's total assets reveal any conclusive effects in the context of acquirers.

Likewise, we failed to capture statistically significant effects with respect to profitability $[1,10,26,30,53]$, capitalization [4, 11]) and asset structure [26]. In this regard, we again point out that in the context of intra-group mergers, different firm-specific factors may play a role compared to those deals that involve non-related banks.

\section{Limitations and future research}

There are certain limitations to our study. First, we were unable to conclude to which extent each merger was decided solely and independently by the parties involved and to which extent they were enforced in a top-down fashion at the group level. Second, our data lack case-by-case information in terms of the year the negotiations started and in subsequence, the year during which the final decision to merge was ultimately made. In other words, our estimation procedure may have — and probably did — use annual observations that were no longer relevant for the end-result. In this vein, 
we also do not know whether the involved banks changed or adapted their behavior during the period, thus potentially influencing their financial figures just before absorption. Third, the single-country focus may limit the generalizability of our results because other jurisdictions and markets may differ substantially from the Finnish banking sector.

In consequence, this paper opens up several avenues for future studies. Since intra-group M\&A has been unexplored in the literature, more studies are needed to investigate the motives behind this type of activity within financial groups. Likewise, investigating other markets and jurisdictions would add to the understanding of the determinants of M\&A among small, regional stakeholder banks. Finally, it would be worthwhile to study "the black box" of the managerial decision-making process leading to a merger of two or more banks within the same group. That is, at which level the deal is instigated: at the group level or by the involved banks themselves, and in case a said distinction can be made, to examine whether different factors play a role in the process.

Supplementary Information The online version contains supplementary material available at https://doi.org/10.1057/s41261-021-00170-4.

Authors' contribution M.H.: conceptualization, data curation, investigation, methodology, writing- original draft preparation. J.S.: supervision, writing- reviewing and editing. N.S.: conceptualization, methodology, supervision.

Funding Open access funding provided by University of Eastern Finland (UEF) including Kuopio University Hospital.

\section{Declaration}

Conflict of interest All authors declare that they have no conflict of interest.

Open Access This article is licensed under a Creative Commons Attribution 4.0 International License, which permits use, sharing, adaptation, distribution and reproduction in any medium or format, as long as you give appropriate credit to the original author(s) and the source, provide a link to the Creative Commons licence, and indicate if changes were made. The images or other third party material in this article are included in the article's Creative Commons licence, unless indicated otherwise in a credit line to the material. If material is not included in the article's Creative Commons licence and your intended use is not permitted by statutory regulation or exceeds the permitted use, you will need to obtain permission directly from the copyright holder. To view a copy of this licence, visit http://creativecommons.org/licenses/by/4.0/.

\section{References}

1. Akhigbe, A., J. Madura, and A. Whyte. 2004. Partial Anticipation and the Gains to Bank Merger Targets. Journal of Financial Services Research 26 (1): 55-71. https://doi.org/10.1023/b:fina. 0000029657.34575.d2.
2. Akkus, O., J.A. Cookson, and A. Hortaçsu. 2016. The Determinants of Bank Mergers: A Revealed Preference Analysis. Management Science 62 (8): 2149-2455. https://doi.org/10.1287/mnsc. 2015.2245.

3. Baselga-Pascual, L., O. del Orden-Olasagasti, and A. TrujilloPonce. 2018. Toward a More Resilient Financial System: Should Banks Be Diversified? Sustainability 10 (6): 1903. https://doi.org/ 10.3390/su10061903.

4. Beccalli, E., and P. Frantz. 2013. The Determinants of Mergers and Acquisitions in Banking. Journal of Financial Services Research 43 (3): 265-291. https://doi.org/10.1007/s10693-012-0138-y.

5. Berger, A.N., C.H.S. Bouwman, and D. Kim. 2017. Small Bank Comparative Advantages in Alleviating Financial Constraints and Providing Liquidity Insurance over Time. The Review of Financial Studies 30 (10): 3416-3454. https://doi.org/10.1093/rfs/hhx038.

6. Berger, A.N., R.S. Demsetz, and P.E. Strahan. 1999. The consolidation of the financial services industry: Causes, consequences, and implications for the future. Journal of Banking and Finance 23 (2-4): 135-194. https://doi.org/10.1016/s0378-4266(98) 00125-3.

7. Bongini, P., M. Di Battista, and E. Zavarrone. 2007. The Value of Relationship Lending: Small Banks in an Era of Consolidation. Economic Notes 36 (3): 209-230. https://doi.org/10.1111/j.14680300.2007.00184.x.

8. Cabo, P., and J. Rebelo. 2005. Why Do Agricultural Credit Cooperatives Merge? The Portuguese Experience. Annals of Public and Cooperative Economics 76 (3): 491-516. https://doi.org/10. 1111/j.1370-4788.2005.00287.x.

9. Caiazza, S., A. Clare, and A.F. Pozzolo. 2012. What Do Bank Acquirers Want? Evidence from Worldwide Bank M\&A Targets. Journal of Banking and Finance 36 (9): 2641-2659. https://doi. org/10.1016/j.jbankfin.2012.06.004.

10. Campa, J.M., and I. Hernando. 2006. M\&As Performance in the European Financial Industry. Journal of Banking and Finance 30 (12): 3367-3392. https://doi.org/10.1016/j.jbankfin.2006.06.006.

11. Carbo-Valverde, S., J. Hagendorff, and M.J. Nieto. 2013. Do Domestic M\&As Impact Bank Risk Profiles? The Case of Spanish Banks. SSRN Electronic Journal. https://doi.org/10.2139/ssrn. 2318142.

12. Carbo-Valverde, S., E.J. Kane, and F. Rodriguez-Fernandez. 2012. Regulatory Arbitrage in Cross-Border Banking Mergers within the EU. Journal of Money, Credit and Banking 44 (8): 1609-1629. https://doi.org/10.1111/j.1538-4616.2012.00546.x.

13. Chiorazzo, V., V. D’Apice, R. DeYoung, and P. Morelli. 2018. Is the Traditional Banking Model a Survivor? Journal of Banking and Finance 97: 238-256. https://doi.org/10.1016/j.jbankfin.2018. 10.008.

14. Correa, R. 2009. Cross-Border Bank Acquisitions: Is there a Performance Effect? Journal of Financial Services Research 36 (2): 169-197. https://doi.org/10.1007/s10693-008-0043-6.

15. Cyree, K.B. 2010. What Do Bank Acquirers Value in Non-Public Bank Mergers and Acquisitions? The Quarterly Review of Economics and Finance 50 (3): 341-351. https://doi.org/10.1016/j. qref.2010.02.002.

16. De Jonghe, O. 2010. Back to the basics in banking? A microanalysis of banking system stability. Journal of Financial Intermediation 19 (3): 387-417. https://doi.org/10.1016/j.jfi.2009.04. 001.

17. DeLong, G.L. 2001. Stockholder Gains from Focusing Versus Diversifying Bank Mergers. Journal of Financial Economics 59 (2): 221-252. https://doi.org/10.1016/S0304-405X(00)00086-6.

18. DeYoung, R., D.D. Evanoff, and P. Molyneux. 2009. Mergers and Acquisitions of Financial Institutions: A Review of the Post2000 Literature. Journal of Financial Services Research 36 (2-3): 87-110. https://doi.org/10.1007/s10693-009-0066-7. 
19. DeYoung, R., W.C. Hunter, and G.F. Udell. 2004. The Past, Present, and Probable Future for Community Banks. Journal of Financial Services Research 25 (2/3): 85-133. https://doi.org/10. 1023/b:fina.0000020656.65653.79.

20. Emmons, W.R., A. Gilbert, and T.J. Yeager. 2004. Reducing the Risk at Small Community Banks: Is it Size or Geographic Diversification that Matters? Journal of Financial Services Research 25 (2): 259-281. https://doi.org/10.1023/B:FINA.0000020665. 54596.f6.

21. Finance Finland. 2019. Finnish Banking in 2018. Retrieved from https://www.finanssiala.fi/en/financial-services/banks

22. Fiordelisi, F. 2009. Mergers and Acquisitions in European Banking. In: Mergers and Acquisitions in European Banking. UK: Palgrave Macmillan.

23. Focarelli, D., F. Panetta, and C. Salleo. 2002. Why Do Banks Merge? Journal of Money, Credit, and Banking 34 (4): 10471066. https://doi.org/10.1353/mcb.2002.0054.

24. Frame, W.S., and T.J. Coelli. 2001. U.S. Financial Services Consolidation: The Case of Corporate Credit Unions. Review of Industrial Organization 18: 229-242. https://doi.org/10.1023/A:10078 31600451.

25. Goddard, J., D. McKillop, and J.O.S. Wilson. 2014. US Credit Unions: Survival, Consolidation and Growth. Economic Inquiry 52 (1): 304-319. https://doi.org/10.1111/ecin.12032.

26. Goddard, J., D. McKillop, and J.O.S. Wilson. 2009. Which Credit Unions are Acquired? Journal of Financial Services Research 36 (2): 231-252. https://doi.org/10.1007/s10693-009-0055-x.

27. Goddard, J., D. McKillop, and J.O.S. Wilson. 2008. The Diversification and Financial Performance of US Credit Unions. Journal of Banking and Finance 32 (9): 1836-1849. https://doi.org/10. 1016/j.jbankfin.2007.12.015.

28. Goglio, S., and P. Kalmi. 2017. Credit Unions and Co-operative Banks Across the World. In The Oxford Handbook of Mutual, Co-operative, and Co-owned Business, ed. J. Michie, J.R. Blasi, and C. Borzaga. Oxford: Oxford University Press.

29. Hankir, Y., C. Rauch, and M.P. Umber. 2011. Bank M\&A: A Market Power Story? Journal of Banking and Finance 35 (9): 2341-2354. https://doi.org/10.1016/j.jbankfin.2011.01.030.

30. Hannan, T.H., and S.J. Pilloff. 2009. Acquisition Targets and Motives in the Banking Industry. Journal of Money, Credit and Banking 41 (6): 1167-1187. https://doi.org/10.1111/j.1538-4616. 2009.00251.x.

31. Hannan, T.H., and S.A. Rhoades. 1987. Acquisition Targets and Motives: The Case of the Banking Industry. Review of Economics and Statistics 69 (1): 67-74. https://doi.org/10.2307/1937902.

32. Hernando, I., M.J. Nieto, and L.D. Wall. 2009. Determinants of Domestic and Cross-Border Bank Acquisitions in the European Union. Journal of Banking and Finance 33 (6): 1022-1032. https://doi.org/10.1016/j.jbankfin.2008.10.017.

33. Huhtilainen, M. 2020. The Determinants of Bank Insolvency Risk: Evidence From Finland. Journal of Financial Regulation and Compliance 28 (2): 315-335. https://doi.org/10.1108/ JFRC-02-2019-0021.

34. Jones, D., and P. Kalmi. 2015. Membership and Performance in Finnish Financial Cooperatives: A New View of Cooperatives? Review of Social Economy 73 (3): 283-309. https://doi.org/10. 1080/00346764.2015.1067753.

35. Kalmi, P. 2017. The role of stakeholder banks in the European banking sector. In Institutional Diversity in Banking. Palgrave Macmillan Studies in Banking and Financial Institutions, ed. E. Miklaszewska, 33-50. Cham: Palgrave Macmillan.

36. Kalmi, P. 2016. Co-operative Banks in Finland. In Credit Cooperative Institutions in European Countries. Contributions to Economics, ed. S. Karafolas, 43-54. Cham: Springer.
37. Karolyi, G., and A.G. Taboada. 2015. Regulatory Arbitrage and Cross-Border Bank Acquisitions. Journal of Finance 70 (6): 2395-2450. https://doi.org/10.1111/jofi.12262.

38. Kowalik, M., T. Davig, C.S. Morris, and K. Regehr. 2015. Bank Consolidation and Merger Activity Following the Crisis. Economic Review 100 (1): 31-49.

39. Köhler, M. 2013. Does non-interest income make banks more risky? Retail- versus investment-oriented banks. Deutsche Bundesbank, Discussion Paper, No 17/2013.

40. Lang, G., and P. Welzel. 1999. Mergers Among German Cooperative Banks. A Panel-based Stochastic Frontier Analysis. Small Business Economics 13 (4): 273-286. https://doi.org/10.1023/A: 1008130918565.

41. Lanine, G., and R. Vander Vennet. 2007. Microeconomic Determinants of Acquisitions of Eastern European banks by Western European banks. Economics of Transition and Institutional Change 15 (2): 285-308. https://doi.org/10.1111/j.1468-0351. 2007.00288.x.

42. Lepetit, L., E. Nys, P. Rous, and A. Tarazi. 2008. Bank Income Structure and Risk: An Empirical Analysis of European Banks. Journal of Banking and Finance 32 (8): 14521467. https://doi.org/ 10.1016/j.jbankfin.2007.12.002.

43. McKillop, D., D. French, B. Quinn, A.L. Sobiech, and J.O.S. Wilson. 2020. Cooperative Financial Institutions: A Review of the Literature. International Review of Financial Analysis 71: 101520. https://doi.org/10.1016/j.irfa.2020.101520.

44. Mercieca, S., K. Schaeck, and S. Wolfe. 2007. Small European Banks: Benefits from Diversification? Journal of Banking and Finance 31 (7): 1975-1998. https://doi.org/10.1016/j.jbankfin. 2007.01.004.

45. Montgomery, H., K. Harimaya, and Y. Takahashi. 2014. Too Big to Succeed? Banking Sector Consolidation and Efficiency. Journal of International Financial Markets, Institutions and Money 32: 86-106. https://doi.org/10.1016/j.intfin.2014.05.005.

46. Moore, R. 1996. Banking's merger fervor: Survival of the fittest? Federal Reserve Bank of Dallas Financial Industry Studies, pp. 9-15. Retrieved from http://search.proquest.com/docview/22409 $1954 /$.

47. Nguyen, T.H., and J.R. Barth. 2020. Community Banks vs. NonCommunity Banks: Where is the Advantage in Local Small Business Funding? Atlantic Economic Journal 48 (2): 161-174. https://doi.org/10.1007/s11293-020-09671-5.

48. Pasiouras, F., S. Tanna, and C. Gaganis. 2011. What Drives Acquisitions in the EU Banking Industry? The Role of Bank Regulation and Supervision Framework, Bank Specific and Market Specific Factors. Financial Markets, Institutions and Instruments 20 (2): 29-77. https://doi.org/10.1111/j.1468-0416.2011.00165.x.

49. Sääskilahti, J. 2016. Local Bank Competition and Small Business Lending After the Onset of the Financial Crisis. Journal of Banking and Finance 69: 37-51. https://doi.org/10.1016/j.jbank fin.2016.04.004.

50. Valkama, P., L. Oulasvirta, and I. Karppi. 2016. Perspectives on the limited emergence of Public Private Partnerships in Finland. In Public Private Partnerships. A Global Review, ed. A. Akintoye, M. Beck, and M. Kumaraswamy, 89-99. Oxon: Routledge.

51. Weiß, G.N.F., S. Neumann, and D. Bostandzic. 2014. Systemic Risk and Bank Consolidation: International Evidence. Journal of Banking and Finance 40: 165-181. https://doi.org/10.1016/j.jbank fin.2013.11.032.

52. Wheelock, D.C., and P.W. Wilson. 2004. Consolidation in US Banking: Which Banks Engage in Mergers? Review of Financial Economics 13 (1): 7-39. https://doi.org/10.1016/j.rfe.2003.09.00.

53. Wheelock, D.C., and P.W. Wilson. 2000. Why do Banks Disappear? The Determinants of U.S. Bank Failures and Acquisitions. 
Review of Economics and Statistics 82 (1): 127-138. https://doi. org/10.1162/003465300558560.

54. Worthington, A.C. 2004. Determinants of Merger and Acquisition Activity in Australian Cooperative Deposit-Taking Institutions. Journal of Business Research 57 (1): 47-57. https://doi.org/10. 1016/S0148-2963(02)00283-7.

Publisher's Note Springer Nature remains neutral with regard to jurisdictional claims in published maps and institutional affiliations.
Matias Huhtilainen is an early stage researcher at the University of Eastern Finland Business School. His research focuses on financial and capital markets regulation. Dr. Jani Saastamoinen is an associate professor at the University of Eastern Finland Business School. His research focuses on small businesses, market regulation and financial decision making. Dr. Niko Suhonen is a university lecturer at the University of Eastern Finland Business School. His research interests include behavioural economics, gambling markets and risk-taking. 